\title{
CLIMATOLOGY OF CYCLONES, ANTICYCLONES AND STORM TRACKS: REVISION OF CONCEPTS
}

\author{
David Mendes ${ }^{1}$ and Monica Damião Mendes² \\ Recebido em 12 maio, 2004 / Aceito em 21 outubro, 2004 \\ Received May 12, 2004 / Accepted October 21, 2004
}

\begin{abstract}
This paper has the finality of describe climatology of extratropical cyclones, anticyclones and storm tracks for the NH and SH. There is a long history of studies on the characteristics of synoptic systems, beginning with classical work on mid-latitude cyclones. For the SH, analyses of pressure data provide extensive statistics of the climatology of synoptic systems. Interestingly, the anticyclones mean central pressure at $38^{\circ} \mathrm{S}$ in JJA and $44^{\circ} \mathrm{S}$ in DJF. SH cyclones are characterized in frequency maximum in the circumpolar trough between about $50^{\circ} \mathrm{S}$ and $70^{\circ} \mathrm{S}$. For the $\mathrm{NH}$ cyclones, the principal findings of the analysis are as follows: In January the primary maxima are in the western North Atlantic, with a peak about $45^{\circ}-50^{\circ} \mathrm{N}$, where there is a secondary peak, over the north-central Mediterranean; These characteristics are similar in April but with decrease in the frequency of centers; In July the frequencies are further reduced and the hemisphere maximum is over eastern Canada at $55^{\circ} \mathrm{N}$; The October pattern resembles that of winter, except that the Atlantic maximum is off southeast Greenland.
\end{abstract}

Keywords: Cyclones, anticyclones, storm tracks, climatology.

RESUMO. Este estudo tem a finalidade de descrever climatologia de ciclones extratropicais, anticiclones e storm tracks para o Hemisfério Norte e Sul, através de revisões de vários papers publicados. Ao longo do tempo, vários estudos foram realizados com características de identificar sistemas sinóticos, com ênfase para ciclones em latitudes médias. Para o HS foram analisados dados de pressão com finalidade de verificar estatisticamente uma climatologia de sistemas sinóticos. No HS oS anticiclones possuem sua pressão média central localizada em $38^{\circ} \mathrm{S}$ e JJA e $44^{\circ} \mathrm{S}$ em DJF. Os ciclones no HS são caracterizados por terem sua máxima frequência acima de $50^{\circ} \mathrm{S}$ e $70^{\circ} \mathrm{S}$, sendo observados máximos ao longo da Península Antárctica $\left(\sim 70^{\circ} \mathrm{S}\right)$; litoral Atlântico da América do Sul, onde ocorre uma maior variabilidade na quantidade de ciclones sazonalmente. Para $0 \mathrm{HN}$, as principais áreas possuem oscilação sazonal, isto é: Em janeiro, a máxima atividade está localizada no oeste do Atlântico Norte, com máximo entre $45^{\circ}-50^{\circ} \mathrm{N}$, e um outro máximo secundário no centro-norte do Mediterrâneo; em abril a região de maior atividade de ciclones, é similar ao registrado em janeiro; em julho ocorrem uma redução na quantidade de ciclones sobre o leste do Canadá; para outubro, as áreas de atuação são semelhantes ao do inverno, exceto no Atlântico Norte e sudeste da Groelândia.

Palavras-chave: Ciclones, anticiclones, storm tracks, climatologia.

Universidade de Lisboa, Departamento de Física, Centro de Geofísica, C8, Campo Grande, Sala: 8.3.19 - 1749-016 Lisboa, Portugal - Tel: (351-21) 7500881; Fax: (351-21) 7500977

1E-mail: dmendes@fc.ul.pt

2E-mail:mcmendes@fc.ul.pt 


\section{INTRODUCTION}

It has been appreciated for a long time that extratropical cyclones are associated with weather and climate in the globe. A comprehensive view was presented for the northern hemisphere by Petterssen (1950), using manual analysis of the frequency of cyclones/anticyclones centers, as well as of cyclogenesis/anticyclogenesis and rates of alternation between high and low-pressure values. Such information is an essential adjunct to the interpretation of mean pressure or height fields (Klein, 1958).

Algorithms to identify cyclones and anticyclones based on pressure or height data are described by Murray \& Simmonds (1991) and Serreze et al. (1993), Blender et al. (1997), for example. The algorithms permit searches to be made for blocks of grid points to detect local pressure minima/maxima. Jones \& Simmonds (1993) also introduce test of curvature to avoid the inclusion of weak systems. The delimitation of anticyclones centers is normally ambiguous because of slack pressure gradients and tendency for weak maxima that may shift irregularly over time, located within the highest closed isobar. System centers are tracked is space and time in order to verify the relative performance of three automated procedures for identifying cyclones and determining their tracks this shows that the scheme of Murray \& Simmonds (1991) identifies the largest number of both systems and tracks (Leonard et al., 1999). An alternative procedure, proposed by Sinclair $(1994,1996)$ is to calculate geostrophic relative vorticity, although this is better suited to cyclones than anticyclones, as the latter have light winds and a wide separation between the loci of pressure maxima and relative anticyclones vorticity maxima.

\section{CLIMATOLOGY OF CYCLONES AND ANTICYCLONES}

For the southern hemisphere (SH), analyses of fifteen years of pressure data provide extensive statistic of the climatology of synoptic systems (Jones \& Simmonds, 1993), updating the early work of Taljaard (1967). Jones \& Simmonds (1993) compare the zonally averaged behavior of the mean sea level pressure, extratropical anticyclones system density, and anticyclone mean central pressure on a seasonal basis. Interestingly, the anticyclone mean central pressure maximum at $38^{\circ} \mathrm{S}$ in JJA and $44^{\circ} \mathrm{S}$ in DJF is located $8^{\circ}-10^{\circ}$ south of the mean subtropical ridge (STR) of high pressure and $5^{\circ}-8^{\circ}$ south of the maximum zone of system density. The intense anticyclones occur poleward of both the ridge and the maximum zone of system density. The poleward side of the STR is affected by frequent and intense lows, whereas the equatorward side generally has undisturbed flow. Anticyclones are most numerous over the eastern subtropical oceans, with fewer over the southern land areas (excluding Antarctica). Anticyclogenesis occurs over the southwestern Atlantic and Indian Oceans and over the Australian Bight and Tasman Sea. The anticyclones generally move eastward and somewhat equatorward, decaying near the oceanic centers of the time-mean anticyclones. These is a bifurcation in the distribution pattern of system density in winter from east of Tasmania to $150^{\circ} \mathrm{W}$; in this sector there are maxima around $30^{\circ} \mathrm{S}$ and $45^{\circ} \mathrm{S}$.

Southern hemisphere extratropical cyclones as analyzed from weather maps for 1974-89 are characterized by a year-round frequency maximum in the circumpolar trough between about $60^{\circ} \mathrm{S}$ and $70^{\circ} \mathrm{S}$ (Jones \& Simmonds, 1993). During winter and the transition seasons this maximum is fed by two branches spiralling towards it; one originates in the Tasman Sea and the other in the South American sector (Jones \& Simmonds, 1993). However, when centers are computed by identifying local minima from $1000 \mathrm{mb}$ level geostrophic vorticity, a different picture emerges. Sinclair (1994) uses European Centre for Medium-Range Weather Forecasts (ECMWF) data from 1980 to 1986 for this purpose, avoiding the bias towards slower/deeper systems in the traditional approach. This analysis thereby takes account of mobile vorticity centers in middle latitudes. These are fairly uniformly distributed and give rise to a primary eastward track between $45^{\circ} \mathrm{S}$ and $55^{\circ} \mathrm{S}$, which also includes heat lows and lee troughs over or near the three land masses. There is a secondary maximum in winterspring associated with the subtropical of South America and in the southern Indian Ocean in winter. Gan \& Rao (1991), using charts for the period from 1979 to 1988 find that the frequency of cyclogenesis in the South America is more in winter (JJA in SH) than in any other season, and found two preferential centers of cyclogenesis for all the season, the first localized over San Mathias Gulf (Argentina) and second localized over Uruguay. Extension of the vorticity analysis to cyclogenesis shows that cyclones typically form in preferred areas in middle latitudes - near the jetstream baroclinic zones and to the east of the southern Andes year-round, as well as off the east coasts of Australia and South America in winter. In the South America, Gan \& Rao (1991) find that baroclinic mechanisms are responsible for cyclogenesis. Systems forming over the oceans intensify over strong gradients of sea surface temperature. More recently Lim and Simmonds (2002) found great concentration of explosive cyclones in SH has a close association with that of strong baroclinicity.

For the NH, twenty year (1958-77) climatology of extratropical cyclones based on more consistent data than the earlier studies is available. Whittaker \& Horn (1984) performed manual frequency counts over $5^{\circ}$ latitude-longitude boxes for mid-season 
months using surface pressure charts. Where as Klein (1957) makes counts at specific times, Whittaker \& Horn (1984) tabulate a system only once in a given box. The principal findings of the analysis are as follows:

a) In January the primary cyclogenesis regions are in the western North Atlantic, with an extension westward towards the Great Lakes, a broad zone in the western and central North Pacific, with a peak about $45^{\circ}-50^{\circ} \mathrm{N}$ extending into the Gulf of Alaska, where there is a secondary peak, and a subsidiary maximum over the north-central Mediterranean (Trigo et al., 1999);

b) In April the pattern is similar but with a decrease in the frequency of centers and a northward shift over the North Pacific, where the activity now begins to the west over China along $50^{\circ} \mathrm{N}$;

c) In July the frequency are further reduced and the hemisphere maximum is over eastern Canada at $55^{\circ} \mathrm{N}$. The other main focus is from the western Pacific to the western Aleutian Islands, with a subsidiary are over China;

d) The October pattern resembles winter, except is in the Gulf of Alaska, and there is little activity in the Mediterranean.

Trends in cyclone frequency in the NH for 1958-97 are examined at the 1000 and $500 \mathrm{mb}$ levels by Key \& Chan (1999), using the National Centers for Environmental Prediction-National Center for Atmosphere Research (NCEP/NCAR) reanalysis. They show that for $60^{\circ}-90^{\circ} \mathrm{N}$, closed lows increased in frequency at $1000 \mathrm{mb}$ in all seasons, but they decreased in frequency at 500 $\mathrm{mb}$ except in winter. In mid-latitudes, the frequency of lows decreases at $1000 \mathrm{mb}$, with increases at $500 \mathrm{mb}$, except in winter. For $0^{\circ}-30^{\circ} \mathrm{N}$, lows became more frequent at both levels in winter and spring and at $500 \mathrm{mb}$ only in summer and autumn. Agee (1991) used three previous analyses of cyclones and anticyclones frequency to examine trends in relation to intervals of warming and cooling in the NH. Based on the works of Parker et al. (1989) on annual $500 \mathrm{mb}$ cyclones and anticyclones frequency over the western hemisphere for 1950-85, Zishka \& Smith (1980) on surface cyclones and anticyclones frequency over North America and adjacent oceans for January and July 1950-77, and Hosler \& Gamage (1956) on surface cyclones in the United States for 1905-54, Agge (1991) suggested that warming (cooling) periods are accompanied by increases (decreases) in frequencies of both cyclones and anticyclones. The results of Key \& Chan (1999) indicate greater complexity. They also found no significant difference in cyclones frequencies between El Niño and La Niña years. In both North America and Europe cyclone frequencies are poorly correlated with the NAO.

The spatial distribution of systems identified by Serreze et al. (1993) and Serreze (1995) during 1973-92, shows that in winter months the cyclones maximum near Iceland extends northeastward into the Norwegian-Barents Sea. In the summer half year this tendency is almost absent. In winter the rate of cyclones deepening and the frequency of deepening events peak in the area of the Icelandic low, southwest of Iceland, with a separate maximum in the Norwegian Sea (Serreze et al., 1997). Cyclogenesis is common in these areas, as well as in northern Baffin Bay. Deepening rates are up to $-6.8 \mathrm{mb}\left(12 \mathrm{~h}^{-1}\right)$ for the Greenland Sea - North Atlantic sector. The combined effects of ice-edge baroclinicity, orographic forcing, and rapid boundary layer modification in off-ice airflows are probably involved. Additionally, these same locations show high frequencies active one with alternating regimes.

Anticyclogenesis has received less attention except for that occurring in polar air (Curry, 1987) and blocking events. A study for the NH identified 1250 events during 1984 (Colucci \& Davenport, 1987). Cases were defined by a twenty-four-hour mean sea level (MSL) pressure change averaging $2.7 \mathrm{mb}$ with a closed isobar (8 mb spacing) appearing on two successive 1200 UTC charts. For the western hemisphere anticyclogenesis is concentrated over Alaska - western Canada, associated with cold air outbreaks, and over covered areas re-intensify. Zishka \& Smith (1980), however, identify an area of winter anticyclogenesis over western Texas, Oklahoma, and Kansas in response to cold air advection in the rear of Colorado lee cyclones. These highs are usually shallow mobile systems. In summer a similar process operates farther north, over southern Alberta.

Boyle \& Bosart (1983) examine the transformation of a polar anticyclone over Alaska into a warm dynamic system of the east coast of the United State over a seven-day period in November 1969. The system is initially confined to the layer below $850 \mathrm{mb}$, although vertical motion associated with the anticyclogenesis extends through the troposphere. The system first moves southward towards the Gulf coast and then recovers northeastward. In the first stages, upper-level vorticity advection and cold air advection lead to subsidence downstream over the anticyclones. The anticyclone moves southward towards the region of maximum descent, forced by the advection. It is supported to the west by a jet streak maintaining a thermal gradient. In the later stages, warm advection in the lower middle troposphere west of the anticyclones forces an upper-level ridge. More recently Pezza and Ambrizzi 
(2003) finding decrease number of extratropical cyclones and anticyclones in the SH, between 1973-1996, with great variability interannual The same other find increase of cyclones with central pressure below $980 \mathrm{hPa}$, as well as, anticyclones above $1035 \mathrm{hPa}$.

\section{STORM TRACKS CLIMATOLOGY}

The al convention Lagrangian approach to defining storm tracks involves tracing the movement of low pressure centers. Such manual investigations of cyclones tracks in midlatitudes began when synoptic weather maps were systematically prepared in the 1850 s and 1860s. Early studies were performed by E. Loomis (1885) for North America, Mohn (1870) for Europe. Loomis (1885) was the first to assemble information on cyclones paths over the northern hemisphere, but a comprehensive analysis was possible only in the mid-twentieth century (Petterssen, 1950; Klein, 1957). Petterssen drew attention to the importance of the zones where there is a high rate of alternation between high and low pressure centers, which he termed pressure ducts. Recently, tracking algorithms have been developed for digital pressure data (Murray \& Simmonds, 1991; Jones \& Simmonds, 1993; Serreze et al., 1993; Blender et al., 1997; Trigo et al., 1999).

A Lagrangian climatology of North Atlantic storm tracks illustrates a further novel methodology (Blender et al., 1997). Cyclonic minima, defined from ECMWF $1000 \mathrm{mb}$ height data at T106 resolution $\left(\sim 1.1^{\circ} \times 1.1^{\circ}\right)$ over $3 \times 3$ grid point, were tracked at six-hour intervals for winter 1990-94. Cluster analysis of the track data defined three groups of storm that are persistent for at least three days - quasi-stationary (representing 56 percents of the total), northeastward moving (27 percent) and eastward moving (16 percents). Those moving northeastward from the east coast of North America about $40^{\circ}-50^{\circ} \mathrm{N}$ toward the Norwegian Sea have a clear life cycle in terms of height anomaly and height gradient, whereas the zonal group has only a weak cycle, and the stationary systems none. Analysis of the zonal $(x)$, meridional $(y)$ and total displacement over time $(t)$ for each group demonstrates that mean-squared displacements of the cyclones follow a power law scaling:

$$
d x^{2}(t)+d y^{2}(t) \approx t^{\kappa}
$$

where $\kappa$ is about 1.6 for the travelling systems, in line with other scaling analyses of geophysical flows, and 1.0 for stationary systems, indicative of random walk type of behavior. The persistence of a northeastward storm track regime averages about five days (three to eight day range), while the zonal regime has a slightly shorter duration.
In the $\mathrm{SH}$, in contrast to the $\mathrm{NH}$, storm track are virtually circum-global, with little seasonal variability (Sinclair, 1997, Gulev et al., 2001). The track density in winter is a maximum between $50^{\circ} \mathrm{S}$ and $60^{\circ} \mathrm{S}$ over the South Atlantic and South Indian oceans and south of $60^{\circ}$ in the South Pacific, with a secondary maximum near $40^{\circ} \mathrm{S}$ across the Pacific, according to Sinclair (1997). This analysis for winters 1980-94 shows the frequency of centers per $5^{\circ}$ latitude circle per month and translation vectors. The maxima shows are in higher latitudes than in earlier studies by the same author, where the grid spacing favoured detection at lower latitudes. Cyclogenesis is most frequent downstream of the east coast of South America and southeast of South Africa, extending south of Australia in a band into the South Pacific around $55^{\circ} \mathrm{S}$.

A weakness of such analyses is the fact that changes in the intensity of the system and its rate of movement have to be taken into account independently. An alternative frame work for the diagnostic analysis of the atmospheric circulation uses the analysis of the variance of the geopotential height field. By high-pass filtering of the data to extract variance in the two to six day range, the behaviour of positive/negative height anomalies can be examined. These are observed to propagate along zonally oriented wave guides. These are close overall similarities between the two sets of patterns. Differences between them are caused by zonal variations in the climatological mean flow, which may displace the cyclones (anticyclones) relative to the corresponding anomaly center (Wallace et al., 1988).

In the SH, high-pass filtering (two to eight day range) of $300 \mathrm{mb}$ height fields for 1979-89 shows a highly zonal storm track from $45^{\circ} \mathrm{W}$ eastwards to $150^{\circ} \mathrm{W}$, centered about $50^{\circ} \mathrm{S}$ in January (austral summer), with a maximum concentration over the South Indian Ocean, In July there is a more asymmetric pattern with a primary track from the South Atlantic through the Indian Ocean around $45^{\circ}-50^{\circ} \mathrm{S}$, curving poleward to $65^{\circ} \mathrm{S}$ at $160^{\circ} \mathrm{W}$. There is no pronounced equatorward displacement of the storm tracks in winter, as occurs in the $\mathrm{NH}$ and the occurrence of maximum midlatitude meridional temperature gradients during austral summer determines the degree of storm tracks activity and the tendency to zonal symmetry. The observed location of the primary storm track just downstream and poleward of the polar jetstream maxima (Trenberth, 1991) is accounted for by linear baroclinic theory for the observed basic state of the atmosphere in the $\mathrm{SH}$, according to Frederiksen (1985). However, James \& Anderson (1984) emphasize the role of moisture entrainment into the low level westerlies over the mid-latitudes of the South Atlantic, downstream of the source in the Amazon Basin, as responsible for the large increase there of transient addy activity. 
The relation between the mean jetstream, the storm tracks, and the associated high frequency eddy statistics for the zonally symmetric circulation in the SH is illustrated schematically in Trenberth (1991). Maximum height variance $\left(z^{\prime 2}\right)$, indicating a high rate alternation, is located along the storm track, whereas perturbations of the vorticity $\left(\zeta^{\prime 2}\right)$ are greatest just equatoward of the track as a result of the variation of the Coriolis parameter and consistent with the geostrophic relationship. Accordingly, perturbations of the meridional wind (v') are displaced correspondingly, but zonal wind perturbations ( $u^{\prime}$ ) have maxima north and south of the storm track. The perturbations are elongated meridionally, thus $\overline{v^{\prime 2}}<\overline{u^{\prime 2}}$, and have a characteristic eastward bowed shape of trough and ridge axes. This generates momentum convergence from eddies into the storm track $\left(\overline{v^{\prime} \zeta^{\prime}>0}\right)$. The perturbations of temperature, $T$ ', are greatest at low levels and are highly correlated with the east-west variations in -v'. Also, maximum perturbations of moisture, $q$ ' and vertical velocity, $\omega^{\prime}$, are closely related and are located in lower latitudes in association with the patterns of v' and T'. Rao et al. (2002 and 2003), study seasonal variation in the $\mathrm{SH}$ storm track characteristic and associated wave propagation, where downstream development occurs throughout the year and is a basic feature of upper tropospheric waves in the midlatitude in the SH.

The traditional mapping of cyclones/anticyclones tracks yields information relevant to determinations of the wind field and the sequence of weather conditions over given locations which is appropriate for many synoptic climatological purposes. Howere, it is the combined effect of the height anomalies in all frequency bands make up the observed circulation pattern at a given time. As pointed out by Trenberth (1991), the cyclonic vorticity advection associated bad weather arise from the advent to a negative height anomaly or the departure of a positive height anomaly.

\section{PROCESS OF FORMATION STORM TRACK}

The formation and maintenance of storm tracks merits explanation. There are two basic hypotheses concerning the development of storm tracks. One considers that the meridional temperature gradients formed by land-sea contrasts induce planetary wave structures through heating and orographic effects that are modified by transient influences. The second idea involves a selforganizing mechanism whereby eddies feed back onto the time mean flow. Recently it has been demonstrated that the statistics of extratropical synoptic eddies can be derived from the assumption that they are stochastically forced disturbances evolving on a baroclinically stable background flow (Farrel \& loannou, 1993).
Further, Whitake \& Sardeshmukh (1998) deduce the observed wintertime statistics of the zonally varying synoptic eddies that that are associated with the observed zonally varying background flows. They use a two level hemispheric quasi-geostrophic model, linearized about the observed mean flow (for 400 and $800 \mathrm{mb}$ winds, 1982-95), and forced by Gaussian white noise. The synoptic eddy covariance is linked with the spatial structure of the background flow and with the covariance of the stochastic forcing by a fluctuation dissipation relationship; this relationship implies that the tendency of eddies to decay is balanced by forcing. The model reproduces most major features of the climatological winter storm tracks over North Pacific and North Atlantic as well as some aspects of their seasonal cycles and interannual variability. Using a similar modelling approach, Whitaker \& Dole (1995) examine the sensitivity of storm track organization to zonally varying large-scale flow. They identify two competing processes that are associated with the locations of a local baroclinicity maximum and a horizontal deformation minimum. If the equilibrium state comprises a zonally symmetric temperature field and a barotropic stationary wave, the storm track is just downstream of a minimum in horizontal deformation in the upper jet entrance zone. However, as zonal variations in baroclinicity increase, the storm track is displaced to the jet exit region just downstream of a baroclinicity maximum. With flows intermediate between these two cases, there are storm track maxima in both the jet entrance and exit zones.

Midlatitude cyclones, at least off east coast of Asia and North America, develop and intensify primarily through baroclinic instability associated with diabatic heating. Hoskins \& Valdes (1990) show that the major North Atlantic and North Pacific tracks, identified using high-pass filtered $250 \mathrm{mb}$ height data for winter 197984 , are centered somewhat eastward and poleward of the regions of maximum column-averaged diabatic heating. Hoskins \& Valdes (1990) show that the storm tracks are characterized by a baroclinic instability parameter due to Eady (1949); the maximum growth rate $\left(\sigma_{B F}\right)$ is

$$
\sigma_{B I}\left(\text { day }^{-1}\right)=0.31 f\left|\frac{\delta V}{\delta z}\right| N^{-1}
$$

where the Brunt- Väisäla frequency: $N=(g \delta \theta)^{1 / 2} /(\theta \delta z)$ is the static stability parameter $\left(N=10^{2} s^{-1}\right)$. Maxima of $\sigma_{B I}$ exceeding 0.6 day $^{-1}$ at the $780 \mathrm{mb}$ level are found over the western North Pacific and Atlantic oceans, implying amplification of systems by factors of 2-3 day ${ }^{-1}$. The horizontal eddy transport of heat in extratropical storms act to reduce the baroclinicity and therefore storm tracks might be expected to shift in time and space as systems move through an area, yet this is not observed be- 
cause vorticity fluxes help to offset the effect. Rather, the storm tracks tend to be self maintaining as a result of the diabatic heating patterns primarily caused by the storm tracks. The E flux vector $\left(\overline{v^{\prime 2} u^{\prime 2},-u^{\prime} v^{\prime}}\right)$ show in Hoskins \& Valdes (1990), diverges from the storm tracks, indicating a tendency for cyclones (anticyclones) circulation on the poleward (equatorward) flanks, which serves to force the mean westerly flow by counteracting the destructive effects of the eddy heat fluxes on the baroclinicity. Orlanski (1998) confirms the increase in the barotropic component of the zonal jet due to the second term of the E flux. Hoskins \& Valdes (1990) use a linear stationary wave model, with representative forcing in the storm track regions, to show that the mean diabatic heating off the east coast of the northern continents in winter provides the necessary environment for storm track maintenance, overriding the thermal effects of the eddies. Nevertheless, the low level winds that arise as a result of cyclones passages set up wind stresses that help to strengthen the Gulf Stream and Kuroshio currents, thereby in turn providing the initial diabatic heating and baroclinicity for the atmosphere.

Climatological storm tracks are commonly identified by maxima in the variance of geopotential height. Large amplitude, high frequency eddies occur preferentially downstream of the major stationary wave troughs at $500 \mathrm{mb}$, giving rise to stationary storm tracks (Blackmon et al., 1977). However, the planetary scale waves oscillate in position, Therefore it is important to understand how travelling storm tracks may more in association with these planetary scale wave. Low frequency (seven to ninety days) and high frequency (less than seven days) components of geopotential height can be separated by taking Fourier components of gridded height values in the frequency domains, for example. Cai \& van den Dool (1991) apply this separation to twice daily $500 \mathrm{mb}$ height for winter $1967-68$ to $1976-77,22^{\circ}-90^{\circ} \mathrm{N}$. At $50^{\circ} \mathrm{N}$ the time averaged amplitude of the stationary waves in the $500 \mathrm{mb}$ height is mainly concentrated in zonal wave number 1 and 2, the amplitudes of the low frequency waves are similar for wave number 1 to 4 and then decrease slowly, while the smaller contribution of high frequency waves is largest for wave number 5 to 8 . The low frequency variability is about twice that of the high frequency component and represents regions of recurring high amplitude anomalies in the central North Atlantic, Gulf of Alaska, western Siberia, and northern Hudson Bay. The high frequency component has a background value of about $40 \mathrm{gpm}$ and maxima of 70 $-80 \mathrm{gpm}$ in elongated zones resembling the storm tracks of the North Atlantic and North Pacific. The high frequency transient eddies reinforce the barotropic component of the stationary waves, i.e. they lose energy barotropically to the stationary waves, whereas the low frequency eddies gain energy from the stationary waves.

Model studies support the idea that storm track anomalies are driven by, and through, feedback effects and may also modify large-scale, low frequency circulation anomalies. Using a series of Global Climate Model (GCM) integrations, Branstator (1995) shows that the distribution of storms can be altered by the barotropic component of the low frequency perturbations through the steering of synoptic systems by the mean winds. Alternatively, storm tracks can be reorganized by changes in the location or intensity of baroclinic zones. However, because the climatological distribution of storms is not random but has distinctive spatial structure, large scale circulation pattern anomalies can redistribute storm tracks such that anomalous momentum fluxes may feedback positively on to the large scale anomalies for some, but not all, of the primary circulation modes observed in the northern hemisphere.

\section{CONCLUSION}

Southern Hemisphere cyclones are characterized by a year round frequency maximum in the circumpolar trough between about $60^{\circ} \mathrm{S}$ and $70^{\circ} \mathrm{S}$, and during winter and transition seasons this maximum is fed by two branches spiralling towards it; one originates in the Tasman Sea and the other in the South American sector.

For the northern hemisphere, in January the primary maxima are in the western North Atlantic, whit an extension westward towards the Great Lakes, a broad zone in the western and central North Pacific, extending into the Gulf of Alaska, where there is a secondary peak over the north-center Mediterranean. In April the pattern is similar but with a decrease in the frequency of centers and a northward shifts over the North Pacific. In July the frequencies are further reduced and the hemispheric maximum is over eastern Canada. The October pattern resembles winter, except that the Atlantic maximum is off southeast Greenland, the main Pacific center is in Gulf of Alaska, and there is little activity in Mediterranean.

There are two hypotheses concerning the development of storm tracks: 1) considers that the meridional temperature gradients formed by land-sea contrast induce planetary wave structures through heating and orographic effects that are modified by transient influences; 2) idea involves as self organizing mechanism whereby eddies feedback onto the time mean flow. 
The focus in this paper has been the documentation the various papers referents the cyclones/anticyclones and storm tracks, and to analyse you're resulted.

\section{REFERENCES}

AGEE EM. 1991. Trends in cyclone and anticyclone frequency and comparison with periods of warming and cooling over the Northern Hemisphere, J. Climate, 4: 263-267.

BLACKMON ML, WALLACE JM, LAU N-C \& MULLEN SL. 1977. An observational study of the Northern Hemisphere wintertime circulation. J. Atmos. Sci., 34: 1040-1053.

BLENDER R, FRAEDRICH K \& LUNKEIT F. 1997. Identification of cyclone track regimes in the North Atlantic. Q J R Met Soc 123: 727-741

BOYLE JS \& BOSART LF. 1983. A cyclones/anticyclones couplet over North America: an example of anticyclone evolution. Mon. Wea. Rev., 111: 1025-1045

BRANSTATOR G. 1995. Organization of storm track anomalies by recurring low-frequency circulation anomalies. J. Atmos. Sci., 52: 207-226.

CAI M \& VAN DEN DOOL HM. 1991. Low-Frequency waves and traveling Storm tracks. I. Barotropic component. J. Atmos. Sci., 48: 1420-1436.

COLUCCI SJ \& DAVENPORT JC. 1987. Rapid surface anticyclogenesis: synoptic climatology and attendant large-scale circulation changes. Mon. Wea. Rev., 115: 822-836.

CURRY J. 1987. Contribution of radiative cooling to the formation of cold-core anticyclones. J. Atmos. Sci., 44: 2575-2592.

EADY ET. 1949. Long and cyclone waves. Tellus, 1: 33-52.

FARRELL BF \& IOANNOU PJ. 1993. Stochastic Dynamics of Baroclinic Waves. J. Atmos. Sci. 50: 4044-4057.

FREDERIKSEN JS. 1985. The Geographical Locations of Southern Hemisphere Storm Tracks: Linear Theory. J. Atmos. Sci. 42: 710-723.

GAN MA \& RAO VB. 1991. Surface cyclogenesis over South America. Mon. Wea. Rev. 119: 1293-1302.

GAN MA \& RAO VB. 1994. The influence of the Andes Cordillera on Transient Disturbances. Mon. Wea. Rev., 122: 1141-1157.

GULEV SK, ZOLINA 0 \& GRIGORIEV S. 2001. Extratropical cyclone variability in the Northern Hemisphere winter from the NCEP/NCAR reanalysis data. Climate Dyn., 17: 795-809.

HOSKINS BJ \& VALDES PJ. 1990. On the existence of storm-tracks. J. Atmos. Sci., 47: 1854-1864.

HOSLER CL \& GAMAGE LA. 1956. Cyclones frequencies in the United State for the period 1905 to 1954. Mon. Wea. Rev., 84: 388-390.
LIM EP \& SIMMONDS I. 2002. Explosive Cyclone Development in the Southern Hemisphere and a Comparison with Northern Hemisphere Events. Mon. Wea. Rev., 130: 2188-2209.

JAMES IN \& ANDERSON DLT. 1984. The seasonal mean flow and distribution of large-scale weather systems in the southern hemisphere: the effects of moisture transports. Quart. J. R. Met. Soc., 110: 943-966.

JONES DA \& SIMMONDS I. 1993. A climatology of Southern Hemisphere extratropical cyclones. Clim.Dynam. 9: 131-145.

KEY JR \& CHAN ACK. 1999. Multidecadal global and regional trends in $1000 \mathrm{mb}$ and $500 \mathrm{mb}$ cyclone frequencies. Geophy. Res. Lett. 26: 2053-2056.

KLEIN WH. 1957. Principal tracks and mean frequencies of cyclones and anticyclones in the northern hemisphere. Res. (40), U.S. Weather Bureau, $60 \mathrm{pp}$.

KLEIN WH. 1958. The Frequency of Cyclones And Anticyclones In Relation To The Mean Circulation. J. of Meteo. 15: 98-102.

LEONARD S, TURNER J \& VAN DER WAL A. 1999. An assessment of three automatic depression tracking schemes. Met. Applic., 6: 173-83.

LOOMIS E. 1885. Areas of low pressure, their form, magnitude, direction and velocity of movement, In: Contributions to Meteorology, Tuttle Moorehouse \& Taylor, New Haven CT, 67 pp.

MOHN H. 1870. Det Norske Meteorologiske Instituts Storm-Atlas, Bengtzen, Chritiania, 26 pp.

MURRAY RJ \& SIMMONDS I. 1991. A numerical scheme for tracking cyclone centres from digital data. Part I: development and operation of the scheme. Aust. Met. Mag., 39: 155-166.

NAKAMURA H \& SHIMPO A. 2004. Seasonal Variation in the Southern Hemisphere Storm Tracks and Jet Stream as Revealed in a Reanalysis Datasets. J. Climate, 17, 1828-1844.

ORLANSKI I. 1998. Poleward deflection of storm tracks. J. Atmos. Sci., 55: 2577-2602.

PARKER SS, HAWES JT, COLUCCI SJ \& HAYDEN BP. 1989. Climatology of $500 \mathrm{mb}$ cyclones and anticyclones, 1950-85. Mon. Wea. Rev., 117: $558-70$.

PETTERSSEN S. 1950. Some aspects of the general circulation. Centen. Proc. Roy. Met. Soc., Roy. Meteor. Soc., 120-155.

PEZZA AB \& AMBRIZZI T. 2003. Variability of Southern Hemisphere Cyclone and Anticyclone Behavior: Further Analysis. J. Climate, 16: 10751083.

RAO VB, DO CARMO AMC \& FRANCHITO SH. 2002. Seasonal Variation in the Southern Hemisphere Storm Track associated wave propagation. J. Atmos. Sci., 59: 1029-1048.

RAO VB, DO CARMO AMC \& FRANCHITO SH. 2003. Interannual Variations of Storm Tracks in the Southern Hemisphere and their connections with the Antarctic Oscillation. Int. j. Climatol., 23: 1537-1545. 
SERREZE MC. 1995. Climatological aspects of cyclone development and decay in the Arctic. Atmosphere-0cean., 33: 1-23.

SERREZE MC, BOX RG \& WALSH JE. 1993. Characteristics of Arctic Synoptic Activity, 1952-1989. Meteorol. Atmos. Phys., 51: 147-164.

SERREZE MC, CARSE F, BARRY RG \& ROGERS JC. 1997. Icelandic low cyclone activity: Climatological features, linkages with the NAO, and relationships with the recent changes in the northern hemisphere circulation. J Climate, 10: 453-464.

SINCLAIR MR. 1994. An objective cyclone climatology for the Southern Hemisphere. Mon. Wea. Rev. 122: 2239-2256.

SINCLAIR MR. 1996. A climatology of anticyclones and blocking for the Southern Hemisphere. Mon. Wea. Rev., 124: 245-263.

SINCLAIR MR. 1997. Objective identification of cyclones and their circulation intensity, and climatology. Wea. Forecasting, 12: 595-612.

TALJAARD JJ. 1967. Development, distribution and movement of cyclones and anticyclones in the Southern Hemisphere during the IGY. J. Appl. Met., 06: 973-987.
TRENBERTH KE. 1991. Storm tracks in the Southern Hemisphere. J. Atmos. Sci., 48: 2159-2178.

TRIGO IF, DAVIES TD \& BIGG GR. 1999. Objective climatology of cyclones in the Mediterranean region. J Climate, 12: 1685-1696.

WALLACE JM, LIM GYU-HO, BLACKMON ML \& MAURICE L. 1988. Relationship between Cyclone Tracks, Anticyclone Tracks and Baroclinic Waveguides. J. Atmos. Sci., 45: 439-462.

WHITAKER LM \& HORN LH. 1984. Northern hemisphere extratopical cyclones activity for four mid-season months. J. Climatol., 4: 297-310.

WHITAKER JS \& DOLE RM. 1995. Orgamization of storm tracks in zonally varying flows. J. Atmos. Sci., 52: 1178-1191.

WHITAKER JS \& SARDESHMUKH PD. 1998. A linear theory of extratopical synoptic eddy statistics. J. Atmos. Sci., 55: 237-58.

ZISHKA KM \& SMITH PJ. 1980. The climatology of cyclones and anticyclones over North America and surrounding ocean environs for January and July, 1950-77. Mon. Wea. Rev., 108: 387-401.

\section{NOTES ABOUT THE AUTHORS}

David Mendes. Graduated in Meteorology at the Federal University of Pará, Brazil (1998). Ph.D. in Meteorology at the University of Lisbon, Portugal (2005). Worked as Meteorologist at CPTEC/INPE, Brazil, from 1999 to 2002. Researcher at the Mangrove Dynamics and Management Project (MADAM) from 1996 to 1998. Consultant satellite Meteorologist at Federal University of Pará, Brazil, from 1996 to 1997. Research interests: Mechanisms and Predictability of long-term Climate variability; Storm Tracks and extratropical Cyclones; Tropical-Extratropical Climate Interaction.

Monica C. Damião Mendes. Meteorologist B.Sc. at Federal University of Pará, Brazil (1998); M.Sc at Federal University of Paraíba, Brazil (1999); Ph.D. at the University of Lisbon, Portugal (2005). Worked as a Meteorologist at CPTEC/INPE, Brazil, from 2000 to 2002 and as a meteorological observer of the Didatic Station (DCA) at Federal University of Paraíba (1993 to 1994). Research interests: climate variability; Synoptic and Weather Prediction; Atmospheric Blocking; Tropical-Extratropical Climate Interaction. 